\title{
'A tale of two cities': The evolution of the International Academy of Practical Theology
}

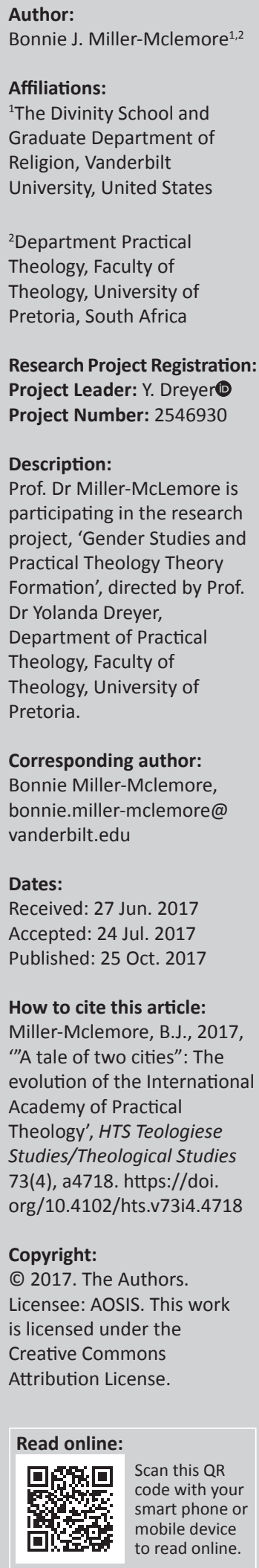

This essay appraises the history of the International Academy of Practical Theology (IAPT), arguing that competing aims have pulled it in different directions. The essay arose initially out of a roundtable on IAPT at an international congress in São Leopoldo, Brazil, in preparation for the next biennial conference there in 2019. Why is there a need for the IAPT? What are some of its developments? Why is it important for South America and Brazil? In response, the essay suggests that the IAPT has struggled to sustain at least two prominent commitments - a desire to enhance practical theology's scholarly visibility and acumen and a real need to become a genuinely international organisation in terms of representation and inclusion. A secondary argument woven through the essay is that collegial friendships across complicated differences of location and perspective have the capacity to moderate and even heal conflicts.

\section{Introduction}

Little attention has been directed at the 25-year history of the International Academy of Practical Theology (IAPT). ${ }^{1}$ Perhaps the rise and fall of academic societies does not spark curiosity among scholars. But practical theologians have reason to be interested. In practical theology, contextual realities matter, and reflexivity is important. So, a closer look at our own internal politics and practices has greater value and place than it might in other disciplines. The IAPT has a telling history, one that says a great deal about disciplinary priorities and frustrations. Indeed, as I hope to demonstrate, we can learn a lot about practical theology by looking more closely at key organisational conflicts and developments.

Learned societies that support disciplines have been around a long time, all the way back to the Académie des Jeux floraux created in 1323 to promote poetry and literature. Theological associations in the United States appeared more recently. Between 1880 and 1930, as historian Clark Gilpin observes (1996:83), 'religious attuned university presidents' such as Charles Eliot at Harvard and William Rainey Harper at Chicago began to make a 'case for theology in the university'. To establish themselves as viable participants, scholars in religion inevitably sought what Edward Farley describes as the 'sociological accoutrements of a science' (1983:105) academic journals, graduate programmes, research delimited by specific methods and subjects, and, of course, national and worldwide collegiums.

Practical theologians are no different on this score. But by comparison to longer standing organisations such as the Society of Biblical Literature founded in 1880, we have been late to the game. I say 'we' because I write from inside as a scholar whose trajectory dovetails that of the IAPT. I had just begun teaching when a handful of people gathered in Princeton in 1991 to create the fledgling association. Growing up academically alongside the association, so to speak, offers a distinct perspective from which to consider its history. I am certainly not objective - a modernist ideal that has come under increasing suspicion during this period in any case. I share some of the organisation's growing pains, I know inside stories that merit telling, and other people would, no doubt, tell different stories. Nonetheless, although my aim is not to air dirty laundry, as the English idiom goes, I do want to go beyond the official record and explore missteps and achievements from which we can learn as we go forward. For truth be told, we - the 150 or so members elected by invitation only based on academic accomplishment - have had our fair share of quarrels and differences.

In answer to the question of IAPT's evolution, I tell a 'tale of two cities', arguing that competing values and aims have pulled IAPT in different directions. Specifically, I suggest that IAPT has 1.1 found two texts with brief treatments of the IAPT: Mikoski and Osmer $(2011: 136-139)$ and Browning $(1999: 157-164)$. Mikoski and
Osmer focus on the financial and ideological support provided by Princeton Theological Seminary. Browning spends the majority of his essay showing how his work on the family demonstrates disciplinary trends behind the 'idea' of the IAPT. 
struggled to sustain at least two prominent commitments - a traditional desire to enhance practical theology's scholarly visibility and acumen and a real need influenced by emancipatory theories to become a genuinely international organisation in terms of representation and inclusion. By focusing on these two ambitions, I do not mean to obscure the complexities, nor do I want to foster a dualism or suggest that there are not other critical controversies. ${ }^{2}$ I know I am weaving a 'tale' that plays off of Charles Dickens's Tale of Two Cities, his rare venture into historical fiction, overstating my case ('it was the best of times, it was the worst of times'). But I study these two commitments because they have figured prominently from the beginning with the hope that my exploration will stimulate further conversation about other desires and aims. At times, our conventional pursuit of scholarly status has come into conflict with a liberationist demand to attend to diversity, local context and injustice. Although we are far from the tumultuous battles between the aristocracy and proletariat of the French Revolution that Dickens imagined in Paris and London, the conflicts are real; they revolve around power, knowledge and the forging of a legacy; and there have been casualties.

\section{International friendships, colonial history and the tale of the International Academy of Practical Theology}

Delving into the strife and value of IAPT may seem fraught with peril, but the endeavour seems particularly worthwhile and relevant for a Festschrift in honour of South African practical theologian Yolanda Dreyer. In a serendipitous but not surprising way, given the international nature of IAPT, this essay is actually linked to South Africa and Brazil and, even more importantly, to women relationships forged in both contexts. One of IAPT's key accomplishments is connecting scholars internationally within countries that have been undergoing considerable change. Indeed, a secondary argument woven through the essay is that collegial friendships across complicated differences of location and perspective have the capacity to moderate and even heal conflicts. To be honest, I travel many miles to academic societies not only because of stimulating plenaries, new reading suggestions and collaborative research, although these are all good. I go to see friends and to envisage the world afresh from their place on the globe.

The question of IAPT's history and purpose arose for me because of a friend. Valburga Schmiedt Streck invited me to participate in the Congresso Internacional da Faculdades at Escola Superior de Teologia (EST) in São Leopoldo, Brazil, in 2016. As part of that invitation, she asked me to join several people in a roundtable on the topic of IAPT - Wilhelm Gräb, an IAPT colleague attending the congress from Humboldt University in Berlin, and three scholars who have taught at

2.For example, people have differed over the role of the arts as an important approach and epistemology in the discipline in contrast to abstract theoretical reasoning and the ploce over the place of Christian proclamation, a matter of importance for evangelical practical theologians but objectionable for those committed to neutral empirica study of religion, concerned about Christian-centrism or interested in interreligious theology.
EST over the years, Valburga herself, Júlio Adam and Christoph Schneider-Harpprecht. Why is there a need for the IAPT, Valburga asked us to consider? What are some of its international developments? Why is it important for South America and Brazil? I had recognised for quite a while that IAPT is often stretched between warring convictions. But I began to see that Brazil, like most IAPT constituencies, is also caught in the crossfire between divergent ambitions that characterises the organisation's history. The roundtable provided opportunity to articulate these thoughts for the sake of a larger cause - preparing the way for the first IAPT conference in South America in 2019.

I first met Valburga at an IAPT conference in South Africa in 2001, 6 years after the country elected its first post-apartheid government, on the campus of Stellenbosch University in the early years of its transformation from a bastion of Afrikaner nationalism. Valburga and I forged an immediate bond. Making our way as white women in a male-dominated profession wedded to patriarchal religious traditions had something to do with our tie, although gender and race similarity never assures instant connection. That we laughed at the same peculiarities is, I think, what really drew us together. I am also grateful to have met Yolanda through IAPT 2 years later when she joined in 2003. As the first Dutch Reformed woman in practical theology in South Africa, she has been a pioneer in her research and teaching. Indeed, her work cuts across the 'two cities' - deserving academic recognition for its scholarly heft but also making a case for greater recognition of minoritised voices.

Through an exploration of IAPT's mixed desires, this essay celebrates Yolanda's success navigating within the 'sacred grove' of the academy. She once told me when I wondered about women's progress (or lack thereof) in practical theology in South Africa that ordination has been a requirement for teaching appointments in her tradition; and, if only men are allowed ordination, only men will hold faculty positions in theology. The Dutch Reformed Church is certainly not unique in this respect. Many Christian traditions and most religious traditions have used scriptural and ecclesial reasoning to keep women silent in congregation and academy. Yolanda, Valburga and I all occupy ambiguous positions as white women in complex race contexts, descendants of European immigrants in countries with notorious race histories. The three of us negotiate the tensions surrounding the divergent aims that mark IAPT history as insiders and outsiders, colonisers and colonised, oppressors and oppressed. How we live out our divergent positions within the academy has serious implications for IAPT's future.

\section{The tale of one city: Intellectual advancement and stature}

The current IAPT website includes two first-person accounts of its history from a couple of original founders, the sole woman, Riet Bons-Storm, then on faculty at the University of Groningen in the Netherlands, and Friedrich Schweitzer from the University of Tübingen in Germany. We can garner 
an initial grasp of the rationale behind the organisation not only from their brief recollections (two pages each) but also from the By-Laws drafted during the 1991 gathering.

The IAPT emerged fairly recently, sparked by a renewed interest in practical theology among scholars in German, Dutch, Canadian and US universities in the 1980s. There was, as Schweitzer reports, a 'convergence of ... developments in different countries' (n.d.:1 of 2) that led to a few international conferences in 1990s, such as a meeting at Tübingen University and a Netherlands-United States conference. In 1991, a handful of well-positioned scholars from prestigious institutions - seven white men and one woman, all European and European-Americans - gathered in Princeton to discuss the possibility of an international society, and the academy was born. It met for the first time in Princeton in 1993.

Clearly, at the forefront of the founders' concerns, the IAPT grew out of a desire to insure and enhance practical theology's place as a university discipline, supporting scholars in their own intellectual development and fostering international conversation, collaboration and publication. The 'need was felt', Bons-Storm observes 'for a broader organization, where practical theologians from all over the world could communicate' (n.d.:1 of 2). Similarly, Schweitzer says that the founders hoped to 'facilitate international research projects as well as to create ongoing exchange on research' (n.d.:1 of 2). He also notes the need for an organisation that includes, under one umbrella, all the subdisciplines of practical theology, each having heretofore its own separate learned society but lacking a place to make broader connections. The opening paragraphs of the By-Laws (n.d.) put these ambitions into formal language, naming five intellectual aims: to 'stimulate various models of research'; to inspire 'new areas of inquiry such as congregational studies and church development'; to develop 'comprehensive frameworks for ordering practical theology itself'; to develop models to account 'for the theoretical coherence and unity of [the sub-] disciplines'; and, finally, to explore the 'relation of practical theology to the other theological disciplines and the modern human sciences'. The creation of the IAPT was a bold and heady venture, giving the small group who came up with the idea a 'passing . . . sense of what God must have felt at the creation of the world', according to Don Browning (1999:157) who actually likens the idea to creation ex nihilo.

Anxiety about academic stature-practical theology as 'scientific and critical' (Browning 1999:158) - is apparent from the start, however. Schweitzer describes the need to be 'taken seriously as a discipline' (n.d.:1 of 2), and Bons-Storm notes the concern about upholding a good 'scholarly image' (n.d.:1 of 2). Perhaps most telling, she describes a debate among the founders over what to call the organisation. Her Dutch colleague, Johannes Van der Ven, wanted to feature the term empirical rather than practical because he feared that the use of practical would diminish or 'make the discipline less scientific, because less theoretical in the eyes of the academic public' (n.d.:1 of 2, emphasis added). He was, she says, 'very outspoken: the name of the discipline had to be "empirical theology"'. He did not prevail. But differences over what characterises genuine intellectual accomplishment 'would have a long life in the IAPT, once founded', as Bons-Storm predicted (n.d.:1 of 2).

For Van der Ven, as for most of the founders, recognition as a science within the modern university was of special, even primary, importance. He was teaching at Radboud University in Nijmegen where the Department of Pastoral Theology had just been renamed the Department of Empirical Theology after a 15-year history of what he describes in his book as an 'intradisciplinary approach' (1993:2) or the adoption of a methodology from one discipline (the empirical sciences) by another (pastoral theology). His worry about academic recognition is clear in his stated aim in the opening paragraph of his book - to lay out an 'empirical method that will stand alongside the literary, historical and systematic approaches already established within the field' (p. vii). The effort faced criticism from within and without. How was such study theological on the one hand? What distinguished it from the psychology and sociology of religion on the other?

Even though Van der Ven did not get his wish in naming the new academy, he continued to pursue the dream of 'empiricaltheological measurement and experimentation' (1993:8) within and beyond IAPT, and his Dutch colleagues and others in Germany, South Africa, Scandinavia and North America have also pressed the same agenda, seeing the employment of objective, repeatable quantitative and qualitative methods as a marker of intellectual credibility and preeminence. For many, practical theology is empirical theology. Practical theology is defined by the use of 'empirical methods and techniques to describe, analyze and evaluate directly theological themes and concepts' (Van der Ven 1993:9). By studying the 'existential, moral, and religious meaning' of practices, according to Hans Schilderman writing 20 years later, also from the University of Nijmegen, 'empirical scholars in practical theology study a domain that is often left fairly uncharted by behavioral and social scientists' who only study the 'motives and consequences' or the 'structures and processes' (2012:124).

In the end, the debate over the organisation's name did lead to what we might call a schism similar to what often happens in religious communities - the creation in 2002 of another organisation, the International Society for Empirical Research in Theology (ISERT). Its connection to the Netherlands and Van der Ven is clear. According to its website, it began after a 'small international group of colleagues in practical theology met at the campus of the University of Nijmegen in order to explore both the opportunity and the possibility' of another learned society. ${ }^{3}$ It was officially founded a year later during its first convention, again in Nijmegen. Van der Ven was the co-founder and first president. Like IAPT, the membership is by invitation only, based on a doctorate or its equivalent and 'a distinguished record of publications'. But, in addition, perhaps to avoid conflicts evident in IAPT, members are 3.See http://www.isert.info/about-isert/, viewed 05 June 2017. 
expected to 'explicitly subscribe to the objective of the ISERT'. Not coincidentally, its membership includes a large percentage of white European and European-American men with membership in both ISERT and IAPT.

In the years following IAPT's creation, scholars tried nonetheless to make it a place for many voices. For example, in an attempt to shape the organisation's future, another Dutch colleague Ruard Ganzevoort advocated during his tenure as president from 2007 to 2009 an intellectual structure that divided scholars for conferences and conversations into three groups - 'ministry formation, liberating practice, empirical research'. These 'three approaches', he proposed, have 'different objects, aims, and central questions and methods, that is, to different practical theological discourses' (2009:28). However, despite his hopes that these categories would offer a commanding rubric, they did not last long beyond his presidential term. Many scholars did not subscribe to his narrow definition of empirical as restricted to quantitative and qualitative methods. They saw their own efforts to offer 'thick description' through a variety of means as essentially an empirical first step in a larger practical theological programme of analysis and constructive and pragmatic response. People also resisted Ganzevoort's designation of audiences or publics for each group, with empirical research aimed at the academy and other areas as invested only in the church or society, a parsing that reflects his own biases. Jaco Dreyer in South Africa, a context influenced by the Netherlands, provides another more palpable example of the pursuit of a middle ground, even if his suggestion has not resolved all the tensions either. He distinguishes as the optimal response to intradisciplinary diversity a 'dialogic pluralist position' over against 'unitary' and merely 'pluralist' approaches (2012:46-54). Rather than viewing diversity as a 'stumbling block on the way to disciplinary integration (a unitary response)' or as a situation to be 'passively accepted and tolerated (a pluralist response)' (p. 49), he sees diversity as an opportunity for productive intellectual engagement. 'We do not only need to respect the variety of approaches', he says, 'but we have to learn to listen to and learn from everyone who joins the conversation' (pp. 53-54).

As Ganzevoort's and Dreyer's efforts reveal, even though people such as Van der Ven questioned IAPT's orientation and intellectual credibility, IAPT members have certainly used its structures for scholarly advancement, thus fulfilling an originating intention, the tale of one city. Among IAPT's most tangible contributions are several key publications. The International Journal of Practical Theology, although not officially a journal of the academy, arose alongside and in close relationship with IAPT with many editorial board members also IAPT members. Initiated in 1997 and now in its twentieth issue, it remains one of the most prestigious and highly ranked journals in the discipline.

Landmark collections have also emerged as a result of IAPT. After the second conference in Bern in 1995, Denise Ackermann and Bons-Storm organised an international collection of feminist work, Faith Practices: Feminist Practical
Theologies in Context (1998) to address ignorance among the largely male membership about the very existence of 'feminist perspectives and their contribution to the formation of practical theology', hoping to be both 'disruptive of dominant male discourse as well as liberating' for those in the discipline (1998:1). Two other edited books grew out of early conferences, according to Schweitzer: Praktische Theologie und Kultur der Gegenwart. Ein internationaler Dialog (Nipkow, Rössler \& Schweitzer 1991) and Practical Theology: International Perspectives (Schweitzer \& Van der Ven 1999). It would be difficult to name all the other collaborative projects with IAPT connections that have arisen since these initial publications. Minimally, 10 conference volumes with approximately 20 papers each have appeared since the 1997 meeting in Seoul, published by Cardiff and Lit Verlag. More recently, the Wiley-Blackwell press chose to include practical theology in its prominent Companion series. As I argue in its introduction, 'Fresh conceptions of practical theology have grown to such an extent that there is a serious need' for such a volume 'to clarify its emerging uses and contributions' (2012:1). Institutional changes have accompanied the intellectual achievements. Universities in Britain and the United States, for example, have created new graduate programmes, and the largest society for religion in North America, the American Academy of Religion, now includes a programme unit on practical theology.

Hence, despite a divergence of opinions about name and approach, a variety of intellectual advances have occurred. Although the meaning of 'practical' in the discipline's name raises perpetual, even tiresome, questions, the discipline has succeeded in establishing itself as equipped to study theology-in-action through a variety of methods. As The Wiley-Blackwell Companion in Practical Theology (MillerMcLemore 2012) attests, scholars in the discipline have moved beyond an early methodological dichotomy between empirical and hermeneutical as the two approaches and now engage multiple means to study theology in practice (e.g., case study, congregational study, ritual theory, poetics, narrative, ethnography, participatory action research and so forth). Indeed, when Gräb joined me in addressing the roundtable at the congress in São Leopoldo, he produced a significant list of accomplishments. By 'investigating ... the processes of religious transformation within specific contexts' and through 'increased contacts beyond our own religious group', IAPT has effected a 'dramatic transformation' of 'selfunderstanding' and definition, moving practical theology from a narrow focus on 'ministry formation to contextual praxis-oriented theories of faith practice' (2016:1).

\section{Tale of another city: Diversity, inclusivity and representation}

Another purpose and hope percolated below the surface from the beginning. In fact, a tale of two cities is apparent in the opening mission statement of the By-Laws (n.d.):

The purpose of the International Academy of Practical Theology is the study of and critical reflection on practical theological thought and action. This critical reflection should be pursued with 
attention to the various historical and cultural contexts in which practical theology is done. Out of respect for the diversity of these contexts, the Academy seeks to promote international, interracial, and ecumenical dialogue and understanding. (emphasis added)

So, the By-Laws situate critical reflection in intricate connection to respect for diversity. Even the inclusion on the website of two accounts of IAPT history testifies to the desire and willingness to make space for differences. Struggles around diversity, however, have arisen in at least three areas, all of which reflect the growing influence of liberation theology and emancipatory theories: gender and race; international representation; and attention to location, politics and poverty.

\section{Gender and race}

The photo of the founders on IAPT's website tells its own story. ${ }^{4}$ By today's standards, the group looks quite white and male, with only Bons-Storm standing alongside Don Browning and Rick Osmer (United States); Karl Ernst Nipkow, Dietrich Rössler and Schweitzer (Germany); Camil Menard (Canada) and Van der Ven (Netherlands). ${ }^{5}$ The near absence of women and the complete absence of people of colour are especially noticeable when we consider the younger scholars in the picture. That is, not all those pictured are senior, but the junior participants are still white and male. Why?

Few women and people of colour had faculty positions in practical theology in 1991, and it is likely that fewer still were involved in the international interchanges that preceded the IAPT's creation. Many were, like me, at the beginning of our careers. However, there were women and people of colour who could have been invited. So, it is likely that these early founders, with the exception of Bons-Storm, did not see greater inclusion as important nor their own gender and race as problematic. Questions of diversity and representation were simply not primary for the white European and European-American men interested in renewing practical theology as a university discipline. If anything, such matters were disconcerting. As Bons-Storm herself observes, 'Some founding fathers were not yet used to have [sic] a woman of equal rank in their midst' (n.d.:1 of 2). Nor, we can surmise, were they accustomed to colleagues of colour.

Bons-Storm, however, could not not notice. 'Another issue at least for me', she writes, 'was gender' (n.d.:1 of 2). Those marginalised for whatever reason - gender, race, class, orientation, ability and so forth - always notice, even as others remain unaware. She describes a 'little incident' over breakfast during the Princeton meeting - what people today might call a microaggression that perpetuates discrimination through small but relentless affronts. A senior male colleague asks her about her marital and parental status, concluding

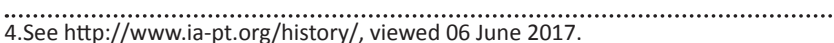
5.Browning (1999:157) includes Norbert Hahn in his list but on IAPT's website Hahn is neither named nor in the picture. Of course, other people not listed in eithe context made early contributions. his 'interrogation' 'rather sternly', after he learns she is married with five children, by saying that she must 'want to have it both ways' (n.d.:1 of 2). He feels vindicated; she feels judged. He probably does not recall the incident. She will remember it for a long time.

Why was there a 'one-generational lag', as I describe it in 1999 , in women's progress in practical theology compared to other disciplines (p. 86)? One obvious reason is the discipline's proximity to congregational life. Congregations are inherently conserving institutions, adept at sustaining traditions over long periods of time. Equally challenging, 'why would one choose further marginalization', I point out, by taking up dicey political issues of inclusion in a discipline already overly aware of its precarious position (Miller-McLemore 1999:87)? In introducing their trailblazing volume, Ackermann and Bons-Storm name similar reasons behind the neglect of feminist voices: 'insecurity' among male practical theologians about 'their identity and purpose as theologians' and anxiety about preserving the church through strong male clergy (1998:1-2). 'When the white, well-educated men ... are insecure about their identity', Ackermann and Bons-Storm conclude, 'they are not eager to let "others" join them' (p. 3).

As a consequence, women have sought each other out as advocates and allies over the years. One particular moment of solidarity merits recording for posterity. At the 1999 biannual conference in Quebec City, marking the end of IAPT's first decade, some of us could not help but notice the predominance of white men among the newly elected members paraded up front after their introduction in the opening session. The all-male cast was the final straw, so to speak, that broke the camel's back for those of us already underrepresented and disempowered during plenaries. In a gestalt of conversation that arose over a shared meal before the meeting concluded (Denise Ackermann, Riet Bons-Storm, Pam Couture, Mary Elizabeth Moore, and Elaine Graham were among those around the table), we found ourselves dreaming up an idea: we would put a motion on the floor at the final business meeting to mandate $50 \%$ female nominees for the next round in 2001. Believing we did not have anything to lose and figuring the motion would go down in any case, Denise said, 'why not go all out? How about eighty per cent women?' So, we drafted a motion that two of us stood up to read the next day, identifying gender inequity as one of several categories needing redress. A few US men spoke in its favour, others who were seldom without words seemed unusually dumbstruck, and, to everyone's surprise, the president called the question and the vote went through (20 for, 6 against, 7 abstentions). ${ }^{6}$

There was fallout, of course. One prominent British scholar took offense, perhaps at the US approach of forcing equality through quotas, and made clear his intention to drop his membership. Van der Ven was also angry, and his decision a year later to support a separate organisation (ISERT) whose 6. Minutes of the Business Meeting, Universite Laval, Quebec City, May 20, 1999. 
membership is largely male and northern European seems a likely consequence. Others worried that there simply were 'not enough qualified women' out there; we could not and would not reach our goal, they predicted.

Obliviousness to sexism and sexist condescension has reared its head over the last few decades in other seemingly harmless incidents that nonetheless conveyed injury and devaluation. The first woman president, Mary Elizabeth Moore, did not receive a slot on the programme for a presidential lecture during the 2001 conference at Stellenbosch. Perhaps simply an oversight, she and other women interpreted it otherwise, as an omission reflective of gender bias in that context and in general. As Heather Walton remarked as she looked forward with some unease to her own presidential address at the 2017 conference, the 'academy does not have a history of treating its female presidents well', although her own positive experience (and my own) attest that change is indeed possible. Looking back, however, Elaine Graham weathered unmerited dissent during business meetings while president in 2007, and the first question Claire Wolfteich fielded when she concluded her 2013 address could easily be interpreted as less than friendly, even antagonistic and disparaging, or at least the question reflected an unwillingness or inability to respect her argument. I use the term fielded deliberately here because men have a history of battlefield and athletic field competition and may not notice when their questions seem combative or shaming. Confrontational debate is presumed as the rule, an assumption about protocol loaded with unique bias. I also use the term interpreted above because I know there are many causes for what may seem like discrimination. Sexism is not always at fault or the singular variable. However, it persists and plays a potent role.

At least women have served as presidents; the academy has yet to elect a person of non-European descent. IAPT members have been even more oblivious of the role and impact of race, racism and our own participation in Western colonial history. In the introduction to their otherwise groundbreaking book of international women authors, Ackermann and Bons-Storm (1998:3) at least recognise the 'whiteness' of their edited collection and lament their failed efforts to recruit authors of other races. The lack of a 'variety of voices from different contexts ... has deprived us of hearing the perspectives of those who know 'otherness' in all its complexity', they state, and raises 'a number of questions which call for ceaseless self-examination' (p.3). Unfortunately, the other landmark international volume that appeared almost simultaneously does not do as well, even though its title, Practical Theology: International Perspectives (Schweitzer \& Van der Ven 1999), suggests a more comprehensive offering. In fact, the editors do not even notice the whiteness or maleness of the contributors (28 of 30 authors are Caucasian; 28 of 30 are men) nor notice or explain their editorial decision to relegate the African and Korean authors to chapters at the end of the book.

At the conclusion of our latest conference in Oslo, when I raised white supremacy and racism as an area needing address during a panel on 'reforming practical theology' (2017b), I felt the silence as deadening. Or this is how I experienced the paucity of comments on the subject during the open discussion that followed brief remarks by four panelists. When I wondered about this silence afterwards with a Norwegian colleague, she noted that people sometimes get tired of the constant US turmoil over race. The issue simply does not press upon people in other contexts in the same way or degree that it does in the United States.

It behoves all of us, however, to reconsider our entanglement in global race history and politics. Phillis Sheppard (2016) presents the challenge vividly in a thoughtful exploration on the conundrum of seeing raced bodies without racist bias and baggage:

Practical theology rarely considers the perspective of those who are not white, and even more rarely allows such persons to speak for themselves. In addition, we see the negative work of racial categories by looking at citation practices across the discipline: we rarely include the work of people of color. Instead, we cite certain field-defining scholars and mentors over and over again. The result is that we reproduce particular perspectives ... and avoid ... expanding our knowledge ... of raced bodies. This leaves (the unacknowledged) white bodies in the driver's seat. (p. 222)

White practical theologians have made our own whiteness invisible. This distorts our reality and our comprehension of other peoples' realities. Sheppard joins womanists, such as Shawn Copeland, in stating the agenda ahead in stark terms: 'telling the truth about white racist supremacy is a theological obligation' (Copeland 2002:21 quoted by Sheppard 2016:245). A practical theology 'that ignores raced bodies', Sheppard concludes, 'is morally defunct' (p. 246).

Back in 2001, despite the naysayers we came close to the $80 \%$ women directive in our nominations for new members prior to the biennial conference. But reaching this quota or any other, on race for example, is partly beside the point. That people had to think about difference as they decided who to nominate, with gender as a temporary category, is of equal or greater consequence. The motion fostered an awakening, a turning point of sorts. However, diversity remains an issue, especially in places around the globe where faculty positions remain intricately linked to prejudiced and patriarchal religious traditions. We especially need to attend to our own on-the-ground actions because they sometimes betray our greater ideals. At the 2017 conference, for example, the first two people to stand and speak after the first plenary were white men, not coincidentally from among the seven founders, perhaps out of a need to re-establish their authority. The sense of male entitlement to take the floor and hold forth never ceases to catch me by surprise, even though it should not. We live with an almost inevitable pendulum swing back to white male dominance in plenaries and elsewhere. Perhaps this tendency is natural in countries with fewer women and people of colour in ranked positions.

Or, is the cause of male dominance in our plenaries something as seemingly innocuous as the stadium seating in venues in Berlin, Pretoria and Oslo, seating which conveys, even if 
unintentionally, assumptions about hierarchy, expertise and priority of voice? Knowledge lies at the centre of the panopticon, as Michel Foucault (1995) might say, down below and upfront, the locus of surveillance, discipline and evaluation. It may be pure coincidence or other factors, but we have done better at making space for diverse voices in Chicago, Toronto and Amsterdam where the seating was on one level, and the overall atmosphere invited equality in cities known for their multicultural and progressive character. How we sit together seems of minor consequence. But for a theological discipline focused explicitly on embodied practices - real bodies and concrete actions - these factors actually matter. We should not need the reminder. Women and people of colour are simply less used to speaking or seeing women and people of colour speak in such contexts. Contexts form us and determine where knowledge resides. Ironically, practical theologians who claim that practices shape knowledge often fail to notice how our own concrete situation determines our work together.

\section{International representation}

The academy has also struggled from the start, according to Bons-Storm, with 'how to be really international, open to the scholarly traditions and possibilities of all national and cultural contexts, willing to learn form [sic] one another' (n.d.:2 of 2). How do we include countries and scholars where financial resources for travel and publications are lacking? 'In many countries', she observes, 'a practical theologian with a $\mathrm{PhD}$ degree does have an enormous workload teaching, is a member of the synod of her/his church, has to sit on numerous committees'. Doctorates 'are so very scarce', and people with professorships have a short list of publications (n.d.:2 of 2). Repeated efforts to raise funds to support the conference participation of those from underserved areas through donation and membership fees have only partially addressed this economic and political issue. Nor has the creation of a working group on "Underrepresented Groups and Regions" made a significant difference.

The effort to host a conference in South America offers an instructive illustration of the challenges and merits closer examination. In the years that followed our first introduction, Valburga and I knew that the academy needed to get to Brazil. Members have gathered from around the globe biannually since 1993 - the United States (1993, 2009), Switzerland (1995), South Korea (1997), Canada (1999, 2013), South Africa (2001, 2015), Britain (2003), Australia (2005), Germany (2007), the Netherlands (2011) and Norway (2017) but never in the southern American continent. Valburga and I plotted and planned before, during and after my tenure as IAPT president from 2009 to 2011, along with several other committed parties. A turning point arose, for instance, when Jaco Dreyer made a special trip to São Leopoldo while IAPT president from 2013 to 2015 to explore the feasibility. With Valburga's ongoing work and that of her EST colleagues such as Júlio Adam, Iuri Reblin and Nilton Herbes, the idea is coming to fruition at last.
A Brazil conference, considered for years as a marker of international progress, has been long in coming. One of my primary reasons for attending the 2016 Congresso Internacional da Faculdades EST that sparked this essay was to present the first plenary on practical theology in the history of the congress (Miller-McLemore 2017a). In fact, it was the first time that the congress included a public lecture, a roundtable and a symposium on practical theology. By making sure that practical theology had a prominent place on the programme, scholars at the school hoped to raise consciousness, foster interest and, especially timely, lay the ground for hosting the 2019 IAPT conference.

Why the difficulties? What have been some of the impediments? There is no simple answer to these questions. There are reasons internal to South America and reasons particular to IAPT of relevance to this essay. Although a vibrant engagement with practical theology has occurred naturally in the German Lutheran seminary in São Leopoldo, a city built in the southern state of Rio Grande do Sul to support German immigration in the mid-nineteenth century, scholars in South America have had far greater interest in the longer standing movement of liberation theology with its parallel but distinct contextual interests. Liberation and contextual theologies receive greater recognition in part because of their deep commitment to grass roots political involvement (see Miller-McLemore 2017a). Moreover, like other South American countries, Brazil is almost threequarters Catholic, and practical theology has often been seen among Catholic scholars as an ecclesial practice focused on the pastoral and sacramental tools of church ministry but not a university endeavour with intellectual accoutrements, such as graduate programmes, learned societies and significant scholarship.

Given the important place of liberation theology and the ambiguous position of practical theology within Catholicism, does Brazil and South America even need practical theology as it has been conceived in its northern, largely Protestant context? Or might this be another instance of imperialist imposition of colonialist ideology on the southern hemisphere? We need to take these questions seriously. In the United States and countries of northern Europe influenced by Lutheran and Reformed Protestant traditions, such as Germany, Norway and the Netherlands, practical theology developed as a twentieth-century discipline in Protestantdominated institutions, and its history is often told in strictly Protestant terms through figures such as Friedrich Schleiermacher. This biased telling ignores Catholicism's unique contributions and distinctive forms of practical theology, evident in its social teachings, for example, or in its spiritual traditions, moral casuistry and sacramental orientation. Will the rising discipline of practical theology complement the work of liberation and contextual theologies in Brazil and Latin America? Or, as Wolfteich worries, will it 'impose an unnecessary or alien discourse on existing Catholic praxis-oriented theology' (2016:279)? Does it perpetuate a 'racism of omission' (Cavazos-González 2011; 
Nanko-Fernández 2010:21) that ignores and neglects Latino/a contributions and thereby risks colonising, again in Wolfteich's words, 'an already flourishing body of theology under a Protestant rubric? Would the language of practical theology simply be redundant, adding little to the Latino/a conversation' and contributing to the 'further marginalization of scholarship by racial/ethnic minorities?' (2016:292).

There are also institutional and pragmatic challenges internal to IAPT. To host a meeting, there must be a sufficient number of faculty in a venue with active interest and participation in IAPT to make the site viable, and, by and large, practical theology has lacked recognition and place as a discipline in its own right in South America. But this reasoning perpetuates a double bind that we need to question: without a conference, we do not foster the discipline; without supporting the discipline, there are not enough scholars to host a conference. And there we are - no conference in South America.

More troubling, in considering Brazil or other southern or eastern hemisphere conference locations, I have occasionally heard colleagues from the north say, usually on the side, 'it's too far to travel' or 'it costs too much to get there', unaware of the privileging behind these words, expecting at the same time our southern and eastern colleagues to travel to Europe or North America. Worries about cost, distance and time are real. But they run both ways, and people in southern and eastern hemispheres often bear the brunt of the expenditure. Given the wealth in northern countries, the offense seems particularly egregious. But it is hard for the privileged to see our own faults. As another example, when members from Brazil proposed a conference theme of decoloniality, a white European woman asked whether 'there would be a place for European theology', implying that colonialism and its legacy have little to do with Europeans? Even though Europe is the font of modern colonialism? As these comments suggest, IAPT members need to be more conscientious and selfreflective about the colonialist roots of modern theology and about our complex locations and interconnections, our reasons for global excursions and our mission in general.

There have also been more credible worries about language difficulties. How would an academy that uses English as the lingua franca function in a country where many people, faculty members included, do not speak English? Language seems like a more legitimate concern than cost and travel time. But these qualms also reflect a bias of another sort. The IAPT has necessarily but rather unselfconsciously adopted English as its working language. Under the heading 'Working Language of the Academy', Item XI, the By-Laws allot one line to what seems a simple matter of fact: 'English shall be the working language of the Academy'. Given the worldwide dependence on English for instant global communication in a market economy, the decision seems self-evident. However, in a continent where Spanish and Portuguese predominate, there is less need to master English than in other contexts. English has this honour, we must also remember, as a result of imperialism, initially of Britain and now of the United States.
In fact, as I discovered in São Leopoldo, some scholars find themselves unfairly judged as inadequate or even unintelligent if they cannot converse easily or well in English. Even though they also speak a language with an ambiguous colonial legacy, today they experience English as a colonising language. Native English speakers in IAPT do not recognise overtly and often enough the advantage we wield or the harm that results from English language dominance. We do not appreciate the work people are doing to move between languages or the break we get because we do not have to translate ideas in our heads or words on the written page from a first to a second language.

\section{Attention to location, politics and poverty}

One final area tests our 'respect for diversity'. Academic achievement and institutional growth have followed the money, as I acknowledge in the introduction to The WileyBlackwell Companion to Practical Theology (2012:15) and in a follow-up essay on the 'hubris and folly' of defining a discipline (2013:150-151). One section of the Companion includes 'hot spots' or places where practical theological scholarship has flourished worldwide. But global hot spots are also spots where wealth has accumulated or economic exploitation has occurred. The economic realities behind academic progress (e.g., higher education requires funding, faculty members publish to earn tenure, presses print books to earn a profit and so forth) raise troubling questions for a theological discipline with commitments to religious traditions that seek justice for the poor and the marginalised. If the IAPT's goal is recognition in the university or status as an academic discipline, concern for the poor may not have a place; but if the aim includes modelling the kind of justice our religious traditions extol, we need to think again. To 'advance' the discipline, as Scottish scholar Eric Stoddart insists, practical theologians must address the 'economic and cultural forces of Empire' - neoliberal imperialism and global capitalism - and their repercussions for the disadvantaged and impoverished (2014:xiv).

Most conferences have included some attention to context with excursions into neighbourhoods to give people a sense of religious and cultural issues that arise in that location. But the primary focus remains, perhaps appropriately, conventional scholarly exchange around papers and plenaries. However, some places demand attention to local context more acutely than others. Prior to the South Africa meeting in 2001, for example, Emmanuel Lartey sent me an email describing concerns he had expressed to the president that would keep him from attending. Ghanaian by birth, educated in Britain, and now a US colleague at Emory University; he draws on his own international identity as a key resource for reflection. He has given me permission to quote his thoughts at length because I believe that they capture well the complicated dynamics behind IAPT's mission to advance the discipline of 'critical reflection' while also 'respecting diversity':

I have been disturbed by the way IAPT functions for a while ... The only real protest I can make is by NOT attending. I have written a fuller explanation to the current President ... spelling 
out my objections. They boil down to the fact that what is proposed is a 'theoretical' conference on poverty and suffering, based at the citadel of Afrikaner strength (the home of apartheid) [Stellenbosch] with a visit to Robben island [sic]! Nothing is proposed which will really bring participants into touch with the real suffering and the on-going struggle especially of the Black majority. Participants will enjoy the 'beauty' of South Africa whilst engaging in theoretical considerations about 'action' on poverty. (personal email correspondence, January 16, 2001)

Lartey's longer memorandum to the president (2000) questions the reigning model of practical theology, its theological and ethical consequences, and its practical political effects. He recognises the need for a 'discipline ... engaging ... in "theological theory"' - a 'theoretical undertaking that builds on a practical basis', quoting the series forward to Gerben Heitink's book, Practical Theology (1999:xv) - but describes his concern about the 'shift away from practice'. We need to 'maintain' the 'tension' (Lartey 2000:1) between theory and practice rather than artificially collapse it in favour of theory. 'I fear', he writes:

the concern of IAPT to promote practical theology as an 'academic' discipline (understood in certain western historical terms) has overridden the concern to maintain the integrity of the discipline itself and to creatively challenge an excessively narrow definition of 'academic discipline'. (p. 2)

Lartey represents well the tale of two cities at odds with each other:

'Generalization' as opposed to 'contextualization' is chosen as the 'respected' form of discourse. The preference of this model, then, is for highly rarified considerations of general cases rather than for the difficult and painful examination of particular cases in detail. The model enables scholars to 'distance' themselves in true modernist western (academic) fashion from any kind of immersion in the context and thus achieve recognition as true scholars. (p. 2)

He concludes, 'what is most crucially lost is our ability to see God's presence in the poor of the world who struggle to survive in the midst of multiple forms of oppression'. We do not examine our very own practice 'from a praxeological or ethical standpoint' (p. 2), asking about its consequences for the communities for whom we serve as advocates.

This problem is not unique to South Africa nor even to IAPT conferences but captures the paradox of practical theology itself - how to attend intellectually and academically to that which can never be contained or adequately addressed through academic means alone (see Bass et al. 2016:226-231). We will always, I argue, come up short on this account, given the inherent and unavoidable tension between reflection and action. How does one do what needs to be done intellectually while also 'taking seriously [the] theological and socio-political context through some significant practical engagement', as Lartey suggests (2000:2)? Practical theologians occupy an odd position: we aspire to become part of the academy in part by critiquing the limits of purely academic theology that ignores pressing everyday needs.

\section{Concluding thoughts: Hopes for Brazil and the International Academy of Practical Theology in 2019}

'Every true beginning has its own myth', Schweitzer writes at the beginning of his account of IAPT's origin. He notices how our efforts to tell the history begin 'to sink into the realm of myth and mystery' (n.d.:1 of 2). I have embellished the myths and mysteries by amplifying IAPT's tensions and ambitions. Do we seek intellectual recognition and accomplishment or international inclusivity and representation of voices? There is no need to resolve the tension between these two cities. IAPT's mission remains plural. Rather, we should focus on the potential benefits of a fuller understanding of IAPT's past as we negotiate and secure its future. International colleagues look with enthusiasm towards a conference in Brazil in 2019 as a wonderful outgrowth of longstanding commitments that will expand the tales of IAPT's mission. So, we might ask instead: What can IAPT do for Brazil to enrich the work of practical theology there, and what will a conference in Brazil do to enliven global conversations about practical theology?

Back to international friendships: Without IAPT, I doubt I would know Yolanda or Valburga. Friendship plays an invaluable role in ensuring creative conversation and intellectual advancement. Both Yolanda and Valburga, it is worth noting, speak with me fluently in English, my first language but not so for them, and Valburga is often translating between German, Portuguese and English until wearied by the effort. I remain grateful, indebted actually, for their efforts. None of us, however, are ultimately 'native' to the contexts we call home, as I noted earlier. Each of us has descended from European ancestors who immigrated sometime in the last few centuries. In other words, we are all products of colonisation in ambiguous positions of power and disempowerment. IAPT's tale of two cities runs through our academic lives and is inherently linked with theological and political controversies that taint Western colonial and postcolonial history, whether or not we recognise our shared culpability and, for many, shared suffering.

Traveling from the United States to South Africa and Brazil as part of the academy's work has revealed troubling and important parallels between our three colonial and postcolonial countries and histories. Brazil imported more Africans as slaves than any other county and was the last country in the Americas to abolish slavery in 1888. It now has the 'largest black population of any country outside of Africa', according to a Brazil AAA guidebook (Egginton 2012:32), although its 'corridors of power are almost exclusively white'. Especially troubling, 'Brazil has never had a black-rights movement ... despite having the largest black population in the western hemisphere' (p. 13). Our meeting is in the whitest region of the country. The United States has its own troubled history despite civil rights movements that lives on today in racist violence and deeply embedded inequities. We share with Dutch Afrikaners conflict with the British, a trek across the country 
exterminating the indigenous on a supposed mission from God, and the fabrication of rigid social and political barriers that segregated and oppressed according to skin colour. Practical theologians must take these realities more seriously.

In all three cases, Christianity played an ambiguous role, justifying race hierarchies and degradation of indigenous knowledge while also, at the very same time, serving as inspiration and means for affirmation of human worth and liberation. Recognising common legacies between nations, made more visible through international friendships, suggests a critical ethical conclusion: practical theology as a discipline has an obligation to recognise and amend its place in this history. Practical theologians and our various constituencies need to secure the good of those most oppressed by colonising Christianity, for we all rise or fall together.

A highlight of my trip to São Leopoldo in fall 2016 was a final meeting among local practical theologians where people talked openly about challenges and hopes for a 2019 IAPT conference. Some people spoke English only; others only Portuguese or Spanish. So, we conducted the meeting in all three languages, with a few wonderfully bilingual people providing translation. I saw people come alive when they were able to speak unfettered in their own language. Here I learned first-hand through honest talk the prejudice and unbecoming dominance English wields. I realised that a 2019 meeting will be most successful if we can provide as many small group seminars as possible where English, Portuguese, and Spanish operate. This strategy may seem like a small move towards inclusion and recognition, but it amounts to much more. Even though this idea puts weight or responsibility on people who are bilingual to serve as translators, it allows for connections across language difference in a context and continent where English is not the lingua franca and probably will not be any time soon. It allows people who are not adept in English to participate and be genuinely heard. As important, it invites those whose first (and perhaps only) language is English to operate at an important deficit for a change. It is time to put native English speakers at a disadvantage.

For the first time in the academy's history, we also need to take up the cost of spontaneous translation for one or more plenaries so that people from Brazil and South America can speak and listen in their native language. Perhaps most important for those who travel from the north: we will need to cultivate and sustain a spirit of respect, generosity and adventure while navigating challenges of travel, new context and language. Only in this way can the IAPT genuinely lend support to scholars, scholarship and teaching in practical theology in Brazil and South America and, in turn, learn from a context where there is much to receive.

During the congress roundtable on the IAPT, Júlio Adam called for a practical theology with the 'face of Brazil' rather than one still dominated by Europe and the northern hemisphere (2016). An important book was published in São
Leopoldo in the 1990s, Teologia Prática no context da América Latina, now in its third edition (eds. Schneider-Harpprecht \& Zwetsch 2011), that helped those in ministry and established an academic legacy in practical theology, making a place for Júlio's own teaching and research. But the volume needs updating; its authors are all men, and many represent a European orientation. What does practical theology look like coming out of Brazil, Júlio asked? There are many pressures today - liberation theology's struggles, interreligious pluralism, Pentecostalism's growth, academic attraction to 'science of religion' and decline of interest in 'theology', and an 'intellectualisation' that intensifies research pressures but requires faculty members to write for state accreditation rather than for religious communities. Can a practical theology be revitalised, he asked, with fresh Brazilian voices that are attentive to the unique challenges?

Júlio answered yes, and, as a new friend, I hope I can be of help. The time has come for IAPT to step up and become a constructive part of the answer to this question and many more such queries that will come our way as scholars discern IAPT's future.

\section{Acknowledgements Competing interests}

The author declares that he or she has no financial or personal relationships which may have inappropriately influenced him or her in writing this article.

\section{References}

Ackermann, D.M. \& Bons-Storm, R. (eds.), 1998, Faith practices: Feminist practical theologies in context, Peeters, Leuven.

Adam, J., 2016, 'Untitled paper', presented at a Roundtable on IAPT, Congresso Internacional da Faculdades, Escola Superior de Teologia, São Leopoldo, Brazil, 15 September.

Bass, D.B., Cahalan, KC., Miller-McLemore, B.J., Nieman, J.R., \& Scharen, C.B., 2016 Christian Practical Wisdom: What it is, Why it Matters, Eerdmans, Grand Rapids.

Bons-Storm, R., n.d., 'The birth IAPT, a personal impression', History, International Academy of Practical Theology, viewed 5 June 2017, from http://www.ia-pt.org/ history/

Browning, D., 1999, 'The idea of the International Academy of practical theology', in F. Schweitzer \& J.A. van der Ven (eds.), Practical theology: International perspectives, pp. 157-164, Peter Lang, Frankfurt am Main.

By-Laws, n.d., International Academy of Practical Theology, viewed 29 May 2017, from http://www.ia-pt.org/organization/

Cavazos-González, G., 2011, 'Racism of omission', in Spiritualitas: On the study of Christian spirituality - sobre el estudio de la espiritualidad cristiana, viewed 6 June 2017, http://spiritualitas.edublogs.org

Copeland, M.S., 2002, 'Racism and the vocation of the theologian', Spiritus: A Journal of Christian Spirituality 2(1), 15-29.

Dreyer, J., 2012, 'Practical theology and intradisciplinary diversity: A response to Miller-McLemore's five misunderstandings about practical theology', Internationa Journal of Practical Theology 16(1), 34-54.

Egginton, J., 2012, Brazil AAA spiral guide, AAA Publishing, Heathrow, FL.

Farley, E., 1983, Theologia: The fragmentation and unity of theological education, Fortress, Philadelphia, PA

Foucault, M., 1995, Discipline and punish: The birth of the prison, Vintage Books, New York.

Ganzevoort, R., 2009, 'Future Plans 2007-2011', Enclosure 10, Business Meeting materials, pp. 26-30, International Academy of Practical Theology, distributed to members.

Gilpin, W.C., 1996, A preface to theology, University of Chicago, Chicago, IL.

Gräb, W., 2016, 'Round table: The International Academy of Practical Theology: Stories and implications', paper presented at a Roundtable on IAPT, Congresso Internacional da Faculdades, Escola Superior de Teologia, São Leopoldo, Brazil, 15 September. 
Heitink, G., 1999, Practical theology: History, theory, action domains, a manual for practical theology, transl. R. Bruinsma, Eerdmans, Grand Rapids, MI.

Lartey, E., 2000, 'Memorandum on IAPT Conference and personal email correspondence', 18 January 2001, larteyey@hhs.bham.ac.uk

Mikoski, G.S. \& Osmer, R.R., 2011, With piety and learning: The history of practical theology at Princeton Theological Seminary 1812-2012, Lit Verlag, Zürich.

Miller-McLemore, B.J.1999, 'Feminist theory in pastoral theology', in B.J. MillerMcLemore \& B.L. Gill-Austern (eds.), Feminist and womanist pastoral theology, pp. 77-94, Abingdon, Nashville, TN.

Miller-McLemore, B.J., 2012, 'Introduction: The contributions of practical theology', in B.J. Miller-McLemore (ed.), The Wiley-Blackwell companion to practical theology, pp. 1-20, Wiley-Blackwell, Oxford.

Miller-McLemore, B.J., 2013, 'The hubris and folly of defining a discipline: Reflections on the evolution of The Wiley-Blackwell Companion to Practical Theology', Toronto Journal of Theology 29(1), 143-174.

Miller-McLemore, B.J., 2017a, 'Teologia Prática: Reforma e transformação na epistemologia teológica' in IA Reblin \& R von Sinner (eds.), Reforma: Tradição e transformação, pp. 35-67, Editora Sinodal, São Leopoldo.

Miller-McLemore, B.J., 2017b, 'Reforming practical theology: Politics, epistemology, (the concluding plenary panel, International Academy of Practical Theology, Oslo, Norway, 24 April.

Nanko-Fernandez, C., 2010, Theologizing en Espanglish: Context, community, and ministry, Orbis, Maryknoll, NY.
Nipkow, K.E., Rössler, D. \& Schweitzer, F. (eds.), 1991, Praktische theologie und kultur der gegenwart. Ein internationaler dialog, Gütersloher Verlagshaus, Gütersloh.

Schilderman, H., 2012, 'Quantitative method', in B.J. Miller-McLemore (ed.), The Wiley-Blackwell companion to practical theology, pp. 123-132, Wiley-Blackwell, Oxford.

Schneider-Harpprecht, C. \& Zwetsch, R. (eds.), 2011, Teologia Prática no context do América Latina [Practical theology in the Latin American context], 3rd edn., Editora Sinodal, São Leopoldo.

Schweitzer, F., n.d., 'The beginnings of the International Academy of Practica Theology', History, International Academy of Practical Theology, viewed 5 June 2017, from http://www.ia-pt.org/history/

Schweitzer, F. \& Van der Ven, J.A. (eds.), 1999, Practical theology: International perspectives, Peter Lang, Frankfurt am Main.

Sheppard, P.I. 2016, 'Raced bodies: Portraying bodies, reifying racism', in J.A. Mercer \& B.J. Miller-McLemore (eds.), Conundrums in practical theology, pp. 219-231, Brill, Leiden.

Stoddart, E., 2014, Advancing practical theology: Critical discipleship for disturbing times, SCM Press, London.

Van der Ven, J.A., 1993, Practical theology: An empirical approach, Kok Pharos Publishing House, Kampen, The Netherlands.

Wolfteich, C.E., 2016, 'Reframing practical theology: Catholic contributions and conundrums', in J.A. Mercer \& B.J. Miller-McLemore (eds.), Conundrums in practical theology, pp. 276-304, Brill, Leiden. 